\title{
What is punk cabaret? An Attempt to Define and Exemplify the Phenomenon
}

\begin{abstract}
The aim of the paper is to present punk cabaret - a new musical phenomenon on the music scene of the English-speaking countries. The author briefly presents its main representatives and cultural contexts, which is followed by an attempt to define the constitutive features of the genre in its musical, performative, and textual aspects. The former consist of prominent vocals, displaying both lyrical finesse and raw, punk-inspired force, with scant accompaniment evoking circus music and pre-war cabaret. Performance, playing a significant role in the genre, adds campy aesthetics and vintage flair. The textual layer, in turn, is characterised by dark humour, moral irreverence, disrespect for the established aesthetic canon, and the orientation towards social margins. All these facets - auditory, visual, and textual — are considered as inseparably intertwined and mutually interrelated in a constant play of contextualisation and allusions, with sound playing a vital role in text interpretation.
\end{abstract}


* e-mail: annamach@post.pl 


\section{Introduction}

What is punk cabaret? Two things it is not are punk and cabaret, although it would probably never have come into being without these two. The new musical genre, revelling in jet-black humour, displaying blatant disrespect for the mainstream aesthetic norms, and wallowing in obscenity, emerged in the recent years in the English-speaking culture. Laughing straight in the face of Mr. Death, punk cabaret artists sing their songs of drollery and despair. What is shocking is often tempting, what is profane becomes a "guilty pleasure", and that may be why punk cabaret has managed to build a small but faithful circle of devoted fans, not only in its native United States and Great Britain, but also abroad. Its recognition in Poland, albeit still modest, is nonetheless discernible in certain theatre productions, recitals, and stage song festivals, which makes this phenomenon worthy of introducing into the Polish academic discourse. Therefore, this paper forms an attempt to present the discussed genre and to define its constitutive features from the musical, performative, and textual perspective. The author will further endeavour to prove that all these three facets remain in constant interplay, where soundscape creates a context affecting the perception of lyrics.

The key artists describing their music as punk cabaret are the British band Tiger Lillies and Amanda Palmer - an American singer-songwriter pursuing a solo career, as well as cooperating with other artists, most prominently within the band Dresden Dolls. In fact, it is Palmer who coined the term Brechtian punk cabaret while in the Dresden Dolls, allegedly in order to avoid being labelled by the media as gotbic (cf. Speer 2006). However, as the genre is rather recent and has not been subject to systematic classification, it should be noted that there is a certain level of liberty in naming it. Other terms, such as dark cabaret, cabaret noir, indie noir, or alternative cabaret, may also be encountered in identical or similar contexts.

\section{Main artists}

Let us now briefly present the main representatives of the genre. London-based band the Tiger Lillies was formed in 1989 by the frontman and songwriter Martyn Jacques, who provides the vocals and plays the accordion. The two other members are presently Adrian Stout on the double bass, and Jonas Golland on the drums (the latter replaced Adrian Huge, who played in the band from its beginnings until 2012). These prolific musicians have so far released more than 40 albums within the span of their over 30-year career. Most of the band's 
songs are written and composed by Jacques. They are, however, frequently inspired by other literary works, such as Victorian cautionary tales (Shockheaded Peter; Tiger Lillies 1998Db) or the artwork of Edward Gorey (Tiger Lillies, Kronos Quartet 2003D). Another instance of intertextuality is the multimedia performance The Tiger Lillies Perform Hamlet (Tiger Lillies 2012Db) presented in many venues, including Gdański Teatr Szekspirowski (cf. Wysocka 2015).

The songs of the Tiger Lillies are a unique combination of pre-war cabaret inspirations, dark humour, gypsy and circus music, and profane lyrics. The usual instrumental set is the accordion, the double bass, and the drums, but occasionally they also play less usual instruments, such as the ukulele, the theremin, and the musical saw. The latter two, in particular, create an eerie ambience with their wailing, melancholy sound. The vocals are usually delivered in a falsetto style, ranging from almost operatic lyricism to aggravating shrieks. The unsettling juxtaposition of the lyrics content, often including profanities, references to violence, sex, and crime, with the angelic voice in which this content is delivered, constitutes just one of many examples of the semantic potential of sound in punk cabaret, recontextualising the lyrics by often placing them in the quotation marks of irony. The band are perhaps too idiosyncratic to belong in a wider subculture, but due to the apparent preference for darkness, as well as the predilection for Victorian outfits and morbid makeup they share certain qualities with goths, who are characterised by the "focus on death and the macabre" (Haenfler 2010: 84).

The band tours extensively, with dozens of live shows every year - worth noting is their ability to adapt to current events, resulting in a prompt release of not one, but two albums about the Covid-19 pandemics (Tiger Lillies 2020 Da ${ }^{1}, 2020 \mathrm{Db}$ ) accompanied by a live performance recorded in the confinement of self-isolation. They have visited Poland on numerous occasions, which results in a certain recognition amongst local audiences. The shows add a visual layer to the perception of their music - they usually perform in Victorian outfits, a greasepaint clownish makeup, and bowler hats. Throughout the performances, they maintain their unusual stage personas, with Jacques moving clumsily about the stage and addressing the audience in his falsetto voice. The bizarre atmosphere is further amplified during some concerts by the presence of other performers, as was the case during a series of Freakshow performances, illustrated by a live contemporary circus act, in the theatre Wintergarten in Berlin in 2010 and 2012 (cf. Tiger Lillies 2010V).

Amanda Palmer presents another - perhaps less extravagant, but more emotionally and politically charged - facet of punk cabaret. The career of this American singer and musician began in the band Dresden Dolls, where she played with the drummer Brian Viglione. The Dresden Dolls were active in the years 2000-2008, then reuniting on several occasions for live shows. In 2007, Palmer moved on with her solo career and to date has released three solo studio albums and a multitude of online recordings. She is also involved in numerous other projects, including collaborative albums with other artists, a memoir book, or a lecture for TED Talks. In 2011, Palmer married the fantasy writer Neil Gaiman and that same year the couple toured with a show of poetry and songs, followed by the album An Evening With Neil Gaiman \& Amanda Palmer (Gaiman, Palmer 2013D).

Songs and performances of Amanda Palmer are characterised by emotional intensity verging on exhibitionism. There is a strong feminist element in her art, as well as a militant

1 Discography entries are listed separately in the References and marked with 'D' followed, where necessary, by further marking with 'a', 'b' etc. for multiple releases of discography by the same author in a given year. 
political stance, manifested mostly in the area of women's rights. During her live shows she openly discusses her personal life with many intimate details, such as the detailed descriptions of her abortions and a miscarriage, engaging the public to share their comments. This emotional exposure is not unfrequently paired with the physical one, as nudity plays a vital role in the artist's stage persona. It should, however, be marked that the image of a naked body seems to be utilised as a means of transgression or empowerment rather than sexual objectification, which is well exemplified by the cover of her third solo album, There Will Be No Intermission (Palmer 2018D) with a photo of the artist posing nude as a triumphant statue holding a sword. The sparse yet fierce piano accompaniment, with the extensive use of stac$c a t o$, forms a befitting auditory frame for her uncompromised tales of violence, rape, abortion, or gender identity, often with autobiographical elements.

While less ironic and more serious than the Tiger Lillies, Amanda Palmer's art nonetheless shares many qualities with them, particularly in its stripped-back, intense acoustic accompaniment, theatrical staging of performances, humour and irony with an undertone of social criticism. These features, together with the inspirations drawn from cabaret, but contrasted with dark, pessimistic, or shocking imagery, usually associated with punk or goth music, are posited in this paper to form the key characteristics of punk cabaret. Nonetheless, it should be noted that due to the highly eclectic nature of the genre it is impossible to create an exhaustive catalogue of its distinctive features and what is proposed below is rather a selection of the main recurring elements, as discussed in the next two sections.

\section{Why so serious? Black humour, camp, carnival}

Punk cabaret artists are clearly continuators and heirs of the distinct Anglophone tradition of using black humour. André Breton (1940/1997: 3) considers this type of humour to have been introduced by Jonathan Swift. Indeed, Swift's A Modest Proposal (Swift 1729/2004) is a classic example of this mode, where the suggestion to overcome Ireland's problems of both poverty and overpopulation by selling infants to be served on English tables is delivered in a deadpan manner, mocking the hypocritical concerns of public opinion and exposing blatant social inequalities, while in the same time provoking laughter that feels utterly inappropriate given the grim context. The tradition of talking about serious matters in a comical way continues to date and is part of the humour of the English-speaking sphere, to name only Monty Python's sketches as a more contemporary example.

Black bumour is an elusive notion, evading unequivocal definitions. As summarised by Patrick O’Neill (1983: 145), “different writers use the term to mean humour which is variously grotesque, gallows, macabre, sick, pornographic, scatological, cosmic, ironic, satirical, absurd, or any combination of these". A definition that seems to succinctly capture the essential elements relevant here is the one from Encyclopaedia Britannica, which describes black humour as "writing that juxtaposes morbid or ghastly elements with comical ones that underscore the senselessness or futility of life [and] make clear that individuals are helpless victims of fate and character" ("Black Humour", n.d.). Three factors play a role here: "dark", uncanny, and scary subjects; comical attitude; and the effect of exposing absurdity or hopelessness.

The art of the Tiger Lillies is an epitome of black humour in the above-mentioned sense. It is expressed not only in the lyrics of their songs, but also on the polysemiotic level, through their stage personas and performance style, as well as the sound setting. They perform in clownish outfits, including greasepaint and bowler hats, often employing funny-looking 
instruments such as a small accordion, a children's drum set equipped with a squeaky rubber chicken, or a miniature banjo (cf. Tiger Lillies 2017V). Many of their songs have playful tunes seeming more appropriate for putting nursery rhymes to music. This ostensibly lighthearted visual and musical side is then juxtaposed with dark subjects such as death, violence, or loneliness. These are often presented in a shockingly straightforward way, forming a striking contrast of the dark and the jolly. The tendency may be exemplified with the song "Heroin \& Cocaine" (Tiger Lillies 1994D: track 4), a merry waltz with exuberant vocals about a child's drug abuse and subsequent decease.

The use of black humour is perhaps less evident, but still present in the case of Amanda Palmer, for instance in "Oasis" (Palmer 2008D: track 10), a song about rape and abortion, where the grave subject is approached in a seemingly lightweight manner with the narrator more interested in receiving autographs of a favourite band than her own trauma. It is worth noting that Palmer claims to have been accused by the British press of "making light" of rape in this song, but responds to this with a pun accurately grasping the role of black humour, saying that it is exactly an artist's role to "make light" where there is darkness (e.g. in an on-stage comment in Munich, 11 September 2019).

As punk cabaret artists position themselves away both from the traditionally understood high-brow, elite art and from the mainstream pop music, and their aesthetics could be perceived as "bad taste", it is worth considering the genre in the light of the concepts of kitsch and camp. Punk cabaret can hardly be claimed to meet the definition of kitsch understood as art meant to please the mass audience, but considered worthless by those educated in art (Kulka 2002: 19, 27), as it lacks the key factors of easy digestibility, cheap prettiness, or mawkish sentimentality. However, as is discussed below, it may certainly be perceived as a manifestation of camp aesthetics.

For the purposes of this paper it is enough to indicate some of key features of camp in order to search for their applicability in the presented case rather than to seek a strict definition of the phenomenon, if this were possible at all (as Gregory W. Bredbeck famously quips, producing a camp answer in itself, "What is Camp? [...] only her hairdresser knows for sure"; Bredbeck 2005: 45). A campy work of art is understood here as one susceptible to being enjoyed in an ironic way for its bad taste, artificiality, or exaggeration.

In the light of what has already been said here about punk cabaret it is evident that it may be considered as camp, or rather as a form of self-conscious, deliberate camping, in the sense proposed by Susan Sontag (1964/2018: 13-16). As for the visual side, both the Tiger Lillies and the stage appearances of Amanda Palmer, particularly with the Dresden Dolls, are marked by exaggerated theatricality, eccentric makeup, and an intensity of gestures and face expressions (cf. Tiger Lillies 2014V and Dresden Dolls 2003V). The "shabby chic" costumes play a vital role in creating this transgressive image: Victorian outfits with a somewhat unkempt clownish edge for the Tiger Lillies, black evening gowns contrasting with messy hairstyles and bare legs for Amanda Palmer. This is further amplified on the auditory level by the mocked operatic falsetto of Jacques and keyboard extravaganzas by Palmer. On the level of lyrics, the frequent focus on extreme perversion, misery, and violence seems almost an invitation to ironic interpretation in a campy style. Examples could be multiplied, as in the song "Maggots" from Farmyard Filth (Tiger Lillies 1997D: track 7), with the lyrics "Left all alone to fade away / Because you lack the social skills / And then grow old and then grow 
ill / To die in filth in filth obscure / To die so dirty and so poor" "2 evoking the words of Oscar Wilde as quoted by Sontag: "One must have a heart of stone to read the death of Little Nell without laughing" (cf. Sontag 1964/2018: 31). The subject of romantic love is, on the other hand, ridiculed, e.g. in a mock love ballad (for a sheep) from the same album (Tiger Lillies 1997D: track 6), with the following verse: "Well there across the farmyard / There goes my love / She's being sheared for summer / I praise God above". All these three aspects - visual, musical and textual - are combined to form the unmistakable campy style of punk cabaret.

Anna Mizerka underlines yet another aspect of camp: that of not belonging, of "screaming one's otherness" (Mizerka 2016: 98; my translation). In this approach, which underlines the serious, subversive potential of the phenomenon rather than its light-hearted playfulness, camp becomes a device for manifesting one's individuality and separating oneself from the mainstream culture. Such a perception also proves constructive for analysing punk cabaret, whose representatives build their identity on a demonstrative lack of respect for aesthetic norms and for gender stereotypes (from the high-pitched voice and the long pigtail of Martyn Jacques to Amanda Palmer sporting body hair in its full splendour). This last aspect also forms a potential to analyse punk cabaret as queer, which, however, exceeds the framework of this paper intended to form an introduction to the analysis of the genre.

The above-mentioned idea of rejecting norms and reversing roles leads to the presence of carnivalisation, as described by Mikhail Bakhtin (1999: 122-137), in punk cabaret. The carnivalistic reversal of roles (cf. Bakhtin 1999: 133), employed in order to expose social inequalities or the hypocrisy of traditional morality, is prominent in numerous songs, mostly those by the Tiger Lillies. Obviously, the carnivalesque thus applied is a means of ironic commentary, a form of "reduced laughter" (Bakhtin 1999: 164) rather than a manifestation of carnivalistic festivities in its original, folkloric form. To offer an example of such an ironic inversion, the whole concept album Here I Am Human (Tiger Lillies 2010Db) describes a world upside down. In fact, "World's Upside Down" (Tiger Lillies 2010Db: track 6) is the title of a song where the totality of lyrics inverses the conventional order of life and death (e.g. "At your birth everybody breaks down and cries / At your funeral they cheer when you have died"). Other instances include the song "Carnival" (Tiger Lillies 2010Db: track 1) with the lines "In this carnival [...] / The holy men are now whores / And the whores with piety do bore"), or "Dirty Slut" (Tiger Lillies 2010Db: track 10): "Everything is topsy-turvy, funny upside-down / The clowns have taken over the running of this town". As may be seen, the quoted passages could easily form an illustration to Bakhtin's images of carnival as inverting the order of the life cycle and the conventional hierarchies of power.

Another carnivalistic feature is a manifest fascination with the bodily "lower stratum" (cf. Bakhtin 1984: 368-436). Songs of the Tiger Lillies referring to genitals or bodily fluids are too numerous to be listed here. The same tendency may be seen in their live performances, where references to excrements are occasionally used to shock the audience in what may be labelled a truly Rabelaisian fashion. Amanda Palmer's focus on the theme of abortions, pregnancies, and miscarriages, so prominent in her recent There Will Be No Intermission tour of music and spoken word, may be perceived as a certain form of a shift towards the lower stratum, this time with a strong political message of women's rights activism.

2 All song lyrics quotations are based on appropriate CD booklets, maintaining the original punctuation. 
The discussed carnivalistic features also occur in a more literal sense, with song themes and musical motifs oscillating around circus, freak shows, or clowns. The Tiger Lillies' album Freakshow (Tiger Lillies 2008D) is in its entirety devoted to the idea of "freaks", or human oddities - snake-women, three-legged men, dwarves, the ugly, the hairy, and the deformed. The album information on the band's official website includes the following sentence: "A carnival of oddities, but who is the freak, them or YOU?" (www.tigerlillies.com/ shop/freakshow). These words allow to see the deeply humane sensibility of presenting this underside of the world, questioning the generally accepted social norms and exposing the hypocrisy of those who marginalise the "freaks" and yet are eager to watch them in a show. A similar feature is visible in Palmer's art: she has performed with Jason Webley dressed as conjoined twins Evelyn \& Evelyn in one specially designed dress (cf. Evelyn Evelyn 2010V), while the "coin-operated boy" from a song by the Dresden Dolls (2003D: track 6; discussed later in this paper) resembles a penny-arcade automaton. The music, frequently modelled after circus fanfares or barrel-organ tunes, strengthens these fairground associations.

\section{Down and out. Social and aesthetic margins in punk cabaret}

The interest in the "lower stratum" is displayed not only on the bodily, but also on the "topographical" level (cf. Bakhtin 1984: 301), via the exploration of social margins. Punk cabaret artists tend to defy traditional concepts of beauty and sublimity, focussing instead on the dark aspects of reality: crime, poverty, substance abuse, emotional distress, and death. As a consequence, their songs are often populated by lowlifes from the margins of society and by the disturbed.

In the case of the Tiger Lillies, even some of the album titles refer to social outcasts: take The Brothel to the Cemetery (Tiger Lillies 1996D), Low Life Lullabies (Tiger Lillies 1998Da), or Cockatoo Prison (Tiger Lillies 2010Da). Many songs tell stories of drug addicts, prisoners and criminals, or prostitutes and pimps. The most condensed example of this gallery of down-and-out characters may be found in the song "Crime" (Tiger Lillies 1996D: track 13), with the following lyrics: "My mother was a prostitute / My father was a thief / My auntie ran a brothel $[. ..] / /$ my sister worked in peep shows [...] / My brother pimped for call girls [...]// My nephew was a rent boy [...] / my niece clipped in Soho". The social dimension of this long list becomes obvious with the final couplet, which ironically comments on the popular saying that "crime doesn't pay" by adding "except when the debt collector needs to be paid". As exemplified above, the band's campy tendency to exaggerate is reflected in a strong accent on the extreme, including the choice of social themes of their songs.

The size of the musical oeuvre of Amanda Palmer, both in her solo career and in various projects, is of significantly smaller scale than the Tiger Lillies' vast discography, which results in a more limited selection of source material. Besides that, the lyrics are usually less explicit and without a linear narrative, unlike those written by Martyn Jacques. Nonetheless, a similar theme of social outcasts may also be traced in the songs of Palmer, where a singing persona (sometimes virtually indistinguishable from the singer) is often an emotionally disturbed and possibly self-mutilating female, a sexual assault victim or a person struggling with the aftermath of an abortion.

To continue, there is a discernible shocking and provocative streak in punk cabaret. The artists defy the standardised canon of popular music in many ways, in particular by using profane language, ridiculing religion, and depicting disturbing or intense scenes. The Tiger Lil- 
lies tend to include numerous profanities in their songs, often whole strings of them, but what they seem to enjoy even more is mocking Christianity to the degree that could probably be considered offensive by some. One of the most striking instances is the song "Banging in the Nails" (Tiger Lillies 1996D: track 3), narrated by an executioner hammering the nails while crucifying Jesus, with a joyful melody contrasted with the lyrics such as "I'm crucifying Jesus, nail him to the cross / The poor old bastard bleeds to death and I don't give a toss". However, taking into account the band's tendency towards black humour and theatricality, such lyrics seem to be a cultural provocation employed for its shock value rather than a genuine assault on religion. That is also confirmed by a comical video to this last song, presenting a scene in a pub with the band playing the song live, while about a dozen "Jesuses" are hanging around, drinking beer and dancing in an energetic moshing style (cf. Tiger Lillies 2013V).

On top of that, the Tiger Lillies frequently depict strong images of violence and sex. The extreme character and the humorous hue of some lyrics lead to the conclusion that they are meant to shock and mock the conventional morality rather than to express any actual opinions of the band. Enough to say that the album Farmyard Filth (Tiger Lillies 1997D) is entirely dedicated to the morally reprehensible phenomena of zoophilia and bestiality, and yet, as the present author has witnessed on multiple occasions during the band's live shows, the audience usually bursts into laughter hearing Martyn Jacques sing in his overexcited falsetto about the practical inconveniences of obtaining carnal knowledge of hamsters or insects.

Amanda Palmer presents a different approach towards a controversial content in her music. Despite the fact that she is an outspoken supporter of the right to abortion, irreverence towards religion is practically absent from her songs. Strong images of violence and sex are present but usually of lower shock value and provocative potential. What she offers instead is a raw emotional fragility that may at times be more unsettling than the facetious extravagance of the Tiger Lillies.

As may be imagined from the above, the discussed genre is far from the easy listening category on the textual level. The same may be extended to the sound setting, where the performers often test the audience's endurance by ear-piercing shrieks, multiple repetitions of the same musical phrase, or prolonged spectacles of coughs and panting. Juxtaposed with the buoyant passages of merry tunes, those moments of auditory pandemonium intensify the ever-present ironic hue of punk cabaret.

\section{Why cabaret? What punk?}

Now that we have sketched the key characteristics of the genre, let us briefly analyse the two main cultural inspirations behind the term punk cabaret: the influence of the Weimar-era cabaret and of punk music and ideology. The genre draws inspirations from the pre-war German cabaret scene and displays particular similarities to The Threepenny Opera of 1928, with the libretto by Bertolt Brecht (1928/2015) and music by Kurt Weill. Ostensibly lightweight, that work in fact constitutes a harsh social criticism of the capitalist system. With its setting amongst the lowlifes and criminals of the Victorian London, and with "playful, quirky tunes [being] the perfect foil for the savage lyrics" (Parker 2015: 246), it seems predestined to serve as a source of inspiration for punk cabaret. In fact, the flirt of punk and the cabaret is not a new phenomenon. For instance, two husky-voiced femmes fatales related, to a degree, to the punk scene, Nico and Marianne Faithfull, have sometimes been labelled "dark cabaret" artists in the media, although their music, while atmospheric and bringing to mind 
Dietrich-like cabaret songs, lacks the element of subversive irreverence and blasphemous irony, so characteristic of punk cabaret. The same may not be said of zestful and theatrical songs of Nina Hagen, displaying unmistakable traits of Kabarett inspirations, confirmed by the artist herself (Hagen 2013), as well as a punky flair. Searching on the Polish scene, the all-female band Los Trabantos has been referred to as cabaret punk rock ("kabaretowy punk rock"; Reiter 2005) and described as using a strategy of parody, pastiche, and provocation (Rynkiewicz 2019: 157-158) so typical of the artists presented in this paper. The term cabaretpunk seems to aptly capture its crucial difference when compared to punk cabaret - while both reach for the cabaret repertoire of irony and exaggeration, only the former operates within the musical paradigm of largely understood rock music with its rhythm-driven electric instrumentation. Punk cabaret, on the other hand, remains outside this paradigm, relying on acoustic accompaniment based on the piano or the accordion and owing more to traditional cabaret or circus music.

Punk cabaret artists are eager to point to Bertolt Brecht as their godfather. The Tiger Lillies describe themselves as an "anarchic Brechtian street opera trio" (www.tigerlillies.com/ band). They also released the album Two Penny [sic!] Opera (Tiger Lillies 2001D), an obvious reference to The Threepenny Opera, but, as the band put it, "one cheaper". The album retells Brecht's narrative in the typical Tiger Lillies style. Several songs include references to Brechtian protagonists: Macky (Macheath) and Polly. For example, the song Moon Over Soho (Tiger Lillies 2001D: track 1) bears manifest similarities to Mack The Knife ("Moritat von Mackie Messer") from The Threepenny Opera. The English version of Brecht's song, translated and adapted by Marc Blitzstein, includes the lines "On the side walk Sunday morning / Lies a body oozing life / Someone sneaking round the corner / Is that someone Mack the Knife?" (Brecht, Weill, Blitzstein: 1954/2000D). The Tiger Lillies' lyrics are strikingly similar: "And the moon shines on a body / And that body oozes blood / Is it Macky with his switchblade / Or is it an act of God?".

There are other works by the Tiger Lillies influenced by the pre-war German art, e.g. the album Lulu. A Murder Ballad (Tiger Lillies 2014D), about the plight of a prostitute Lulu, based on the turn-of-the-century plays Erdgeist (Earth Spirit) and Die Büchse der Pandora (Pandora's Box) by Frank Wedekind (1895/2009; 1904/2010). Another example is The Story of Franz Biberkopf (Tiger Lillies 2015D), an album based on the novel Berlin Alexanderplatz by Alfred Döblin (1929/2019), set in the criminal underworld of the pre-war Berlin.

Amanda Palmer, as mentioned before, admits the inspiration with Brecht by using the term Brechtian punk cabaret with regard to her music. Her song The Killing Type (Palmer 2012D: track 3) mentions Mack the Knife ("I walk New Orleans with a knife / Like Mackie hidden out of sight"). On the humorous side, Palmer uses a keyboard of the brand Kurzweil, with the logo transformed into "Kurt Weill" in a DIY manner.

After having considered the cabaret aspect, it is worth searching for punk in punk cabaret. Evidently, it is not on the acoustic level that the genre, with its mostly unplugged instrumentation and slower, variable tempo, draws the main inspiration from punk, characterised by minimalist compositions, fast pace, and a "dirty" sound of electric guitars. One should rather analyse potential influences on the conceptual level, by analysing the non-musical elements of punk.

To define punk as an ideology is not an easy task, as it is a "notoriously amorphous concept" (Sabin 1999: 2). Moreover, over the years it has become fashionable and consequently its definition has grown more and more imprecise. As rebellion apparently sells well, punk is 
now a label attached to many products and ideas - as a proof of sorts, one may use a search engine to look for some seemingly preposterous phrases, such as "punk lipstick", "punk candle", or even "punk recipes", receiving thousands of records each time. For the sake of the present considerations, however, punk may be construed as an anarchic rejection of the existing order (both social and aesthetic). This rejection, stemming from the pessimistic disillusionment expressed in the slogan "No Future", results in a rebellious and nihilistic attitude refusing the mainstream standards of beauty and propriety. Hence, punk art is irreverent, full of profanities, and it respects no taboos, up to the point of calling the British monarchy "a fascist regime" (Sex Pistols 1977D: track 5). There is also an ironic, self-deprecatory streak in punk; it is clearly visible not only in the stage image of The Sex Pistols blankly staring into the void, bearing striking resemblance to Monty Python's Gumbys (cf. the photos in Blake 2008: 27, 38), but also in their lyrics, e.g. in Anarchy in the U.K. (Sex Pistols 1977D: track 8) where the allegedly subversive acts include giving a wrong time or stopping a traffic line.

Punk cabaret shares many features with punk attitude as defined above: the rejection of mainstream culture, shocking and irreverent demeanour, predilection for profanities. The Dresden Dolls explicitly use the iconic opening line of Anarchy in the U.K. in one of their songs. The Tiger Lillies' Slough (Tiger Lillies 1996D: track 5) could easily provide lyrics for a punk song about growing up in a town of no perspectives ("I'll sing you a song / If you drop a bomb on Slough"), while Repulsion (Tiger Lillies 1994D: track 20) sounds as antiaesthetic as many punk songs ("Vomit stains mixed with blood / Someone somewhere is in love / Repulsion, repulsion”). Moreover, Amanda Palmer shares many qualities with the Riot Grrrl movement, that in turn grew from punk. Enough to mention her anti-consumerist motto "We Are The Media", her militant stance in feminist issues such as the abortion rights, and her image contesting traditional femininity (for more on the corresponding features of the Riot Grrrl subculture see Haenfler 2010: 116-117).

\section{Semantic relevance of sound and image in punk cabaret}

A song is always a work of plurisemiotic character, combining the textual and musical layers with the performative expression (cf. Franzon 2008: 376), and this is no different in case of the discussed genre. Moreover, the artists presented here act as singers-songwriters: authors of both the lyrics and the music, as well as performers (cf. Strachan, Leonard 2003), thus utilising the textual, musical, and visual codes as channels of their artistic expression. Indeed, one may name numerous songs representing the genre where the acoustic layer holds semantic value and enriches or modifies the potential understanding of the text. Some of instances have already been discussed in the paper and below are selected additional examples of the interrelation of sound and text (and, occasionally, of the visual component) in punk cabaret.

One of such instances is "XYZ" by the Tiger Lillies (1999D: track 9), where a melodious, undulating tune to a $6 / 8$ rhythm evokes associations with the blues music and with its tendency towards woeful tunes. This, combined with a plaintive sound of string instruments and of the accordion, creates a melancholy, sorrowful mood, allowing for the associations with a blues lament. Such cultural allusions, although present on the auditory rather than the verbal level, affect the reception of the lyrics, containing an alphabetical list of the singing persona's flaws and failures, and steer their reading towards an intimate confession, a rueful musing rather than a self-flagellating reproach. Thus, it is the sound that guides the audience through the semantic potential of ambiguous lyrics. 
In other cases, sound may amplify the semantic content of lyrics rather than recontextualise it, as in another Tiger Lillies' song, Gin (Tiger Lillies, Kronos Quartet 2003D: track 4). Here, the narrative - a tragicomic tale of a character falling prey to the evils of the eponymous substance - is complemented with an appropriate accompaniment following a vivacious $2 / 4$ rhythm, mirroring the picaresque story of the protagonist undergoing a string of exotic adventures, punctuated by a regular consumption of gin. For the last stanza, however, describing his eventual demise, the tempo is abruptly changed from an energetic vivace to a more than three times slower, sombre largo. This, combined with the accordion imitating a church organ and with eerie sounds of the musical saw or the theremin, constitutes an appropriate musical setting to the scene of the protagonist's funeral. The funereal theme is further expressed by the aposiopesis before the last stanza, where a long pause may be seen as a rhetoric tool symbolising death (cf. Lisecka 2018: 17). This is occasionally further accentuated on the performative level during live performances, when the band members stand up and take off their hats as if saluting the deceased (cf. Tiger Lillies 2019V).

Perhaps the most evident example of the unity of sound and text in punk cabaret may be found in Coin-Operated Boy by the Dresden Dolls (2003D: track 6). The song describes the female narrator's ostensible admiration for her automatic coin-operated boyfriend, the relationship with whom is much simpler than the real-life complications of love. The ironic lyrics praise many advantages of the artificial lover, with a subliminal message of actual loneliness. The instantly recognisable tune accompanying the lyrics resembles a barrel organ or a music box and - in its automatic repetitiveness - forms a coherent unity with the subject of the song. Yet, as the textual narrative reveals discords and dissonances in the automatised relationship, so does the music. At one point the accompaniment and the vocal "jam" and repeat the same halted phrase several times, as if the internal mechanism of the coin-operated boy was not working properly. Complemented on the visual side with the drummer Brian Viglione acting as the robotic beau both during the band's live shows (cf. Dresden Dolls 2013V) and in the official video (Dresden Dolls 2009V), the song is a proof that auditory and visual facets are not just of formal or "ornamental" function, but that they constitute essential carriers of semantic value in a song.

\section{Summary}

The brief presentation of punk cabaret attempted above is by no means an exhaustive depiction, but rather an invitation to further research. What may, nonetheless, be concluded from the above-listed features is the omnipresent irony in commenting the social reality and the human condition as such. The use of transgressive black humour, as well as the musical component ranging from nostalgic music-box tunes to aggravating clangour, expose the tension between the usually grim content and its sardonic presentation. Numerous references to a circus, in music, outfits and lyrics, underline the artificiality of the spectacle and amplify the ironic distance to the described reality. Often rebellious and blasphemous, punk cabaret manages to go beyond punk-influenced nihilism to convey the messages of social criticism or reflections on human frailty, in what may be encapsulated as: "Isn't it hilarious how horrid life is?"

At the same time, the genre contests the generally accepted canon of "prettiness" and of an easy aesthetic pleasure, offering instead a plunge into the dark, which includes the drastic imagery of death and abuse. However, this sombre stylistics always maintains an ironic edge, 
with the condensation of shocking images so dense that it cannot be perceived but as a joke. The tongue-in-cheek quality of punk cabaret also means that it is considered here to possess the qualities of camp, manifested in its exaggeration, theatricality, and the tendency to mock the mainstream art and the widely accepted cultural norms. This mockery and ridicule seem to differentiate it from many other countercultural phenomena in alternative music, such as black metal or gothic rock, which — in general — lack these satiric traits.

The genre makes extensive use of the stylistic tool of a carnivalistic reversal of values, where the ugly becomes beautiful and the evil is good. This not only connects it with the whole tradition of questioning authority through laughter, but is also a form of rejecting widely accepted aesthetic and social norms, in line with the general image of punk cabaret as a subversive movement refusing to adapt to the popular standards. One of the facets of this rebellion is the irreverent, crude language and often shocking choice of imagery. This quality seems common with the punk ideology with its anarchic rejection of generally accepted standards of beauty or appropriateness, even if the two genres differ significantly on the musical level.

Finally, as exemplified above, the genre is marked by a distinct auteur imprint, perhaps due to its niche character and the considerable level of reliance on live performances. As any musical genre, it may not be analysed on a purely textual level but embraced as a plurisemiotic whole, where the sound, the word and the image intertwine in a constant mutual semantic amplification or recontextualization.

The above-formulated conclusions are hoped to form a starting point for further research regarding more specific issues, exceeding the scope of this paper. This could cover, for instance, the political potential of the genre, the queer element in punk cabaret, or semantic shifts appearing in the process of reception in Poland.

\section{Bibliography}

Bakhtin Mikhail (1984), Rabelais and His World, trans. H. Iswolsky, Indiana UP, Bloomington. - (1999), Problems of Dostoevsky's Poetics, ed. \& trans. C. Emerson, University of Minnesota Press, Minneapolis.

Black Humour (n.d.), Encyclopaedia Britannica, www.britannica.com/topic/black-humor [access: 22.06.2019].

Blake Mark (ed.) (2008), Punk. The Whole Story, Dorling Kindersley, London.

Brecht Bertolt (1928/2015), The Threepenny Opera, ed. \& trans. R. Manheim, J. Willet, Bloomsbury, London. 
Bredbeck Gregory W. (2005), Narcissus in the Wilde. Textual cathexis and the historical origins of queer Camp [in:] Meyer M. (ed.), The Politics and Poetics of Camp, Routledge, London, p. 44-64.

Breton André (1940/1997), Anthology of Black Humor, trans. M. Polizzotti, City Lights Books, San Francisco.

Döblin Alfred (1929/2019), Berlin Alexanderplatz, trans. M. Hoffman, Penguin Classics, London.

Franzon Johan (2008), Choices in Song Translation. Singability in Print, Subtitles and Sung Performance, "The Translator", vol. 14, no. 2, p. 373-399.

Haenfler Ross (2010), Goths, Gamers, \& Grrls. Deviance and Youth Subcultures, Oxford UP, New York.

Hagen Nina (2013), Interview, “The Quietus”, https://thequietus.com/articles/12300-ninahagen-musik-kabarett-brighton-festival-interview [access: 22.11.2020].

Kulka Tomas (2002), Kitsch and Art, The Pennsylvania State University, University Park.

Lisecka Małgorzata (2018), Narzędzia nauk o muzyce $w$ badaniach nad piosenką: analiza demonstratywna - rekonesans, "Tekstualia”, no. 2 (53), p. 7-19.

Mizerka Anna (2016), Kamp po polsku, Wydawnictwo „Poznańskie Studia Polonistyczne”, Poznań.

O'Neill Patrick (1983), The Comedy of Entropy: The Contexts of Black Humour, "Canadian Review of Comparative Literature", vol. 10, no. 2, p. 145-166.

Parker Stephen (2015), Bertolt Brecht. A Literary Life, Bloomsbury Methuen Drama, London.

Reiter Paulina (2005), Dziewczyny robia scenę, "Wysokie Obcasy", www.wysokieobcasy.pl/wysokie-obcasy/1,96856,2626746.html [access: 22.11.2020].

Rynkiewicz Beata (2019), "Jestem wtedy, kiedy krzycze...” Postawy emancypacyjne polskich artystek $w$ kulturze punk [in:] Osiński J., Pranke M., Tański P. (eds.) Kultura rocka 1. Twórcy, tematy, motywy, Wyd. Naukowe UMK, Toruń, 149-164.

Sabin Roger (1999), Introduction [in:] idem (ed.), Punk Rock. So What? The Cultural Legacy of Punk, Routledge, London, p. 1-13.

- (1964/2018), Notes on 'Camp', Penguin Books, London.

Speer Deborah (2006), The Dresden Dolls, Pollstar.com, www.pollstar.com/article/the-dresden-dolls-50517 [access: 20.06.2019].

Strachan Robert, Leonard Marion (2003), “Singer-Songwriter” [in:] Shepherd J., Horn D., Laing D., Oliver P., Wicke P. (eds.), Continuum Encyclopedia of Popular Music of the World (vol. II), Continuum, London, p. 198-201.

Swift Jonathan (1729/2004), A Modest Proposal and Other Prose, Barnes \& Noble Books, New York.

Wedekind Frank (1914), Erdgeist (Earth Spirit): A Tragedy in Four Acts, trans. S.A. Eliot Jr., Albert and Charles Boni, New York, Project Gutenberg, www.gutenberg.org/ files/29682/29682-h/29682-h.htm [access: 1.08.2019].

- (1918), Pandora's Box: A Tragedy in Three Acts, trans. S.A. Eliot Jr., Boni and Liveright, New York, Project Gutenberg, www.gutenberg.org/files/33415/33415-h/33415-h.htm [access: 1.07.2019].

Wysocka Katarzyna (2015), Punkowa szydera w kottuna, czyli The Tiger Lillies w Gdańsku, "Gazeta Świętojańska", gazetaswietojanska.org/index.php?id=2\&t=1\&page=51099 [access: 24.08.2019]. 


\section{Discography}

Discography entries are marked with ' $D$ ' followed, where necessary, by further marking with 'a, 'b' etc. for multiple releases of discography by the same author in a given year.

Brecht Bertolt (original text), Weill Kurt (music), Blitzstein Marc (English adaptation) (1954/2000D), The Threepenny Opera [perf. by 1954 Original Off-Broadway Cast], Decca Broadway, CD.

Dresden Dolls, The (2003D), The Dresden Dolls, 8ft, Records, CD.

Evelyn Evelyn (2010D), Evelyn Evelyn, 8ft, Records, CD.

Gaiman Neil, Palmer Amanda (2013D), An Evening With Neil Gaiman \& Amanda Palmer, 8ft, Records, CD.

Palmer Amanda (2018D), There Will Be No Intermission, 8ft, Records, CD.

- (2008D), Who Killed Amanda Palmer, Roadrunner Records, CD.

Palmer Amanda, The Grand Theft Orchestra (2012D), Theatre Is Evil, 8ft, Records, CD.

Sex Pistols, The (1977D), Never Mind the Bollocks Here's the Sex Pistols, Virgin Records, CD.

Tiger Lillies, The (1994D), Births Marriages and Deaths, Misery Guts Music, CD.

- (1996D), The Brothel to the Cemetery, Misery Guts Music, CD.

- (1997D), Farmyard Filth, Misery Guts Music, CD.

- (1998Da), Low Life Lullabies, Misery Guts Music, CD.

- (1998Db), Shockheaded Peter. A Junk Opera, Misery Guts Music, CD.

- (1999D), Bad Blood + Blasphemy, Misery Guts Music, CD.

- (2001D), Two Penny Opera, Misery Guts Music, CD.

- (2008D), Freakshow, Misery Guts Music, CD.

- (2010Da), Cockatoo Prison, Misery Guts Music, CD.

- (2010Db), Here I Am Human, Misery Guts Music, CD.

- (2012Db), Hamlet, Misery Guts Music, CD.

- (2014Db), Lulu. A Murder Ballad, Misery Guts Music, CD.

- (2015D), The Story of Franz Biberkopf, Misery Guts Music, CD.

- (2020Da), Covid-19, Misery Guts Music, MP3.

- (2020Db), Covid-19. Volume II, Misery Guts Music, MP3.

Tiger Lillies, The, Kronos Quartet (2003D), The Gorey End, Misery Guts Music, CD.

\section{Video Material}

Video material entries are marked with ' $\mathrm{V}$ ' followed, where necessary, by further marking with 'a, 'b' etc. for multiple releases of video material by the same author in a given year.

Dresden Dolls, The (2003V), The Dresden Dolls Debut CD Release, YouTube, www.youtube. com/watch?v=09TRhCSny6w [access: 3.07 .2019 ].

- (2009V), Coin-Operated Boy [official video], YouTube, www.youtube.com/watch?v=j4gPZPKJc0s [access: 26.08.2019].

- (2013V), Coin-Operated Boy [live in Sydney], YouTube, www.youtube.com/watch?v=7EYvLNsdChI [access: 30.08.2019].

Evelyn Evelyn (2010V), Evelyn Evelyn [live in Antwerp], YouTube, www.youtube.com/watch?v=HfOJISVLa_E [access: 30.08.2019]. 
Tiger Lillies, The (2010V), The Tiger Lillies Freakshow [trailer], YouTube, www.youtube.com/ watch?v=LeuJoTs6MT8 [access: 24.08.2019].

- (2013V), Banging in the Nails, YouTube, www.youtube.com/watch?v=SvA8NPAl2Dg [access: 28.08.2019].

— (2014V), Living Hell [official video], YouTube, www.youtube.com/watch?v=H54qEy4hrqs [access: 26.08.2019].

- (2017V), Heroin [live at Atlas Club, Kiev], YouTube, www.youtube.com/watch?v=IvwWbtO8QrQ [access: 22.08.2019].

- (2019V), The Tiger Lillie's performs "Gin" live at Joe's Pub in New York City, YouTube, www. youtube.com/watch?v=W9JAfegr040 [access: 5.10.2020]. 